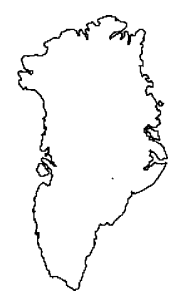

\title{
Geology and petroleum prospectivity of the region offshore southern West Greenland - a summary
}

\author{
James A. Chalmers, Trine Dahl-Jensen, Kevin J. Bate \\ and Richard C. Whittaker
}

Since 1987, the Geological Survey of Greenland (GGU) has been engaged in a re-assessment of the geology and petroleum potential of the region offshore southern West Greenland. In 1994, a milestone was reached in this study when, for the first time, a fairly complete understanding of the regional structure and stratigraphy of all of the sedimentary basins and the continental margin offshore southern West Greenland was achieved. This paper presents an account of how the work was carried out and gives a summary of the geological results. Due to the area being offshore, its investigation required the interpretation of geophysical data, primarily seismic data, tied to boreholes.

\section{The first phase of exploration - 1970s and early 1980s}

It is nearly 25 years since the first multichannel seismic surveys were conducted by the oil industry at the start of a search for hydrocarbons off southern West Greenland. Between 1970 and 1975, much of the shelf between latitudes $62^{\circ} \mathrm{N}$ and $70^{\circ} \mathrm{N}$ was surveyed by a regional grid of multichannel seismic lines (Fig. 1). More detailed surveying followed the award of licences in 1975, and this first phase of exploration culminated in the drilling of five exploration wells in 1976 and 1977.

GGU was also active offshore southern West Greenland during the 1970s. Geophysical surveys, including shallow seismic acquisition, were undertaken in 1972 (Denham, 1974) and 1978 (Brett \& Zarudzki, 1979), and Roksandić (1979) published an interpretation of high resolution seismic surveys acquired by industry.

The understanding of the regional geology that resulted from this first phase of exploration was summarised by Manderscheid (1980) and Henderson et al. (1981). Rolle (1985) summarised the stratigraphy and lithology encountered by the five boreholes and Toxwenius (1986) reported on the biostratigraphy.

\section{Re-appraisal - 1987 to present}

\section{Re-interpretation of seismic data from the 1970s}

In 1987 , a pilot project showed that the new methods of seismic stratigraphy and structural analysis could be used successfully on the 1970s seismic data (Chalmers, 1989). As a consequence, projects were started to reinterpret the remainder of the 1970s seismic data and data from the wells to re-assess the structure and stratigraphy of the West Greenland shelf south of $68^{\circ} \mathrm{N}$. These projects are still incomplete, but interim reports and papers summarising some of the results have been published (Chalmers, 1990; Ottesen, 1991 a, b; Chalmers \& Pulvertaft, 1993; Chalmers et al., 1993).

\section{Continent-ocean transition in the Labrador Sea}

Interpretation of seismic data during the pilot project also suggested that the area of block-faulted continental crust under the continental shelf extended beyond the previously assumed position of the transition from continental to oceanic crust (Tucholke \& Fry, 1985). One seismic line (BGR/77-12), from a seismic survey acquired by Bundesanstalt für Geowissenschaften und Rohstoffe (BGR) in 1977 (Hinz et al., 1979), appeared to show that the fault blocks extended at least $150 \mathrm{~km}$ beyond the continental slope. However, this interpretation was equivocal because the original processing of the data was only to cdp-stack. Reprocessing and migration were necessary.

A trial was carried out by reprocessing and migrating $275 \mathrm{~km}$ of line BGR/77-12. This was successful and the seismic line and associated magnetic data were interpreted to show that continental crust extended well beyond the continental slope (Chalmers, 1991). The results from the trial were sufficiently significant to justify reprocessing and interpretation of an additional $2670 \mathrm{~km}$ of BGR/1977 data (Chalmers \& Laursen, 1995). The location of the reprocessed BGR/1977 seismic lines are shown in Fig. 1.

\section{Acquisition of new seismic data}

The new interpretation of the extent of continental crust off southern West Greenland showed that there were extensive areas with little or no seismic data coverage that might be prospective for petroleum. In order to investigate these areas and other areas thought to be prospective for petroleum, new seismic data were acquired by GGU in 

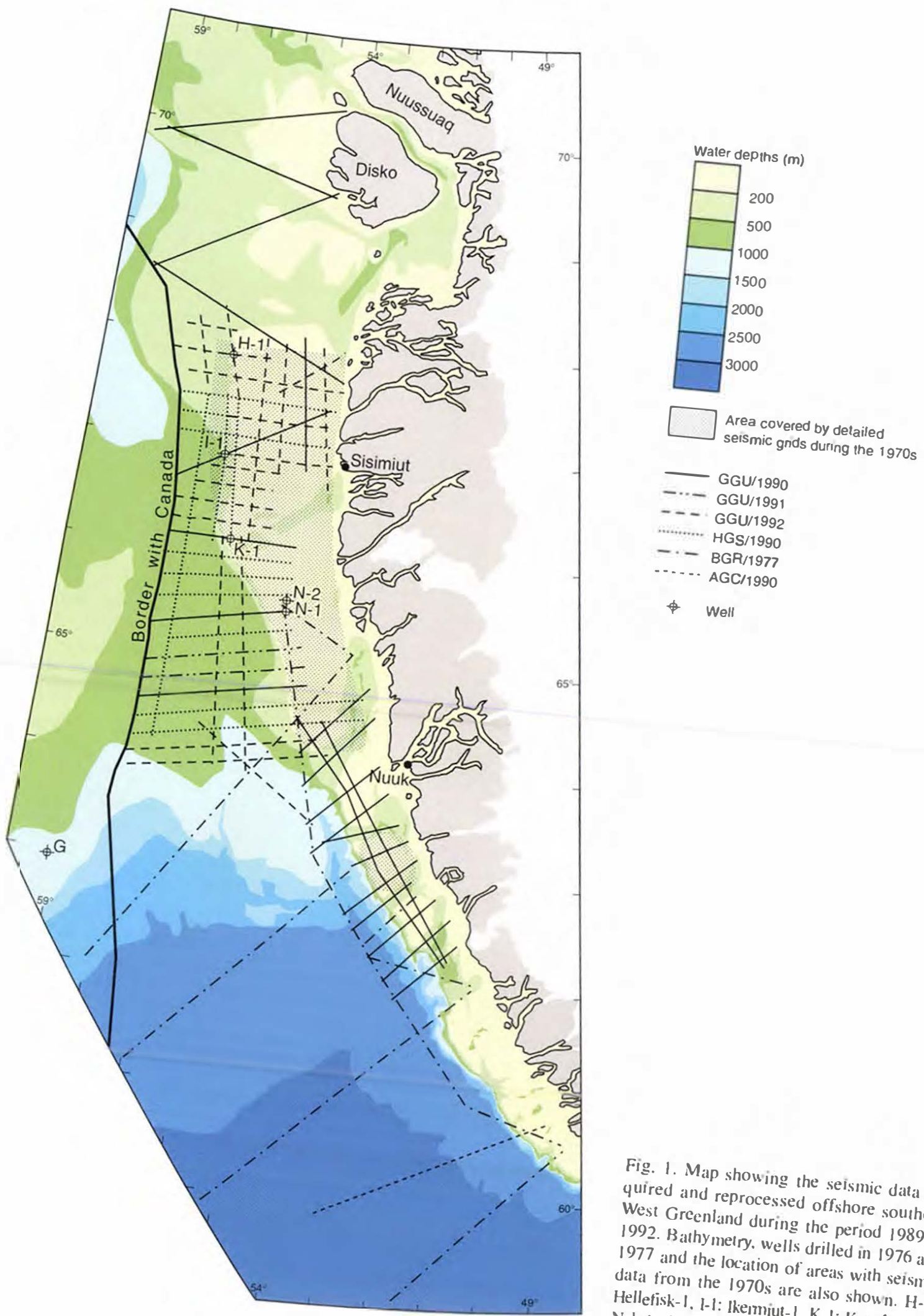

Fig. 1. Map showing the seismic data acWest and reprocessed off shore souther 1992 1992. Bathy metry. wells drilled in 1976 to 1977 and the location of areas in 1976 and data from the 1970 of are as with seismic Hellefisk-1, 1-1: 970s are also shown. H-I N-1: Nukik-1, N-2. Nukik-1, K-1: Kangâıniut-1. 
1990 (Chalmers \& Dahl-Jensen, 1991), 1991 (Christiansen \& Pulvertaft, 1992) and 1992 (Christiansen et al., 1993).

Furthermore, in 1990 'speculative' seismic data were acquired by the contractor, Halliburton Geophysical Services Inc. (HGS), after completion of the GGU/1990 survey. The HGS/1990 survey was designed by GGU at HGS's request, but was not completed because of the increasing frequency of winter storms at the end of the season.

In all, $8553 \mathrm{~km}$ of new data were acquired between latitudes $62^{\circ}$ and $70^{\circ} \mathrm{N}$ in the years $1990-92$ (Fig. 1). A summary of the projects involving acquisition and/or reprocessing of seismic data in the period 1989 to 1992 is given in Tables 1 and 2 .

\section{Table 1. Summary of projects involving acquisition and/or processing of seismic data}

\begin{tabular}{|c|c|}
\hline Project: & REEVALUERE DYBVANDSOMRÅDE \\
\hline \multicolumn{2}{|c|}{ Type of project: reprocessing } \\
\hline Total km: & 275 \\
\hline Funding: & EFP-89 (Energiforskningsprogram 89) \\
\hline Project: & REPROCESSERING GRØNLAND \\
\hline \multicolumn{2}{|c|}{ Type of project: reprocessing } \\
\hline Total km: & 2670 \\
\hline Funding: & EFP-90 and GGU \\
\hline Project: & GGU/1990 \\
\hline \multicolumn{2}{|c|}{ Type of project: acquisition and processing } \\
\hline Total km: & 3285 \\
\hline Funding: & $\begin{array}{l}\text { MRA (Mineral Resources Administration for } \\
\text { Greenland) }\end{array}$ \\
\hline Project: & HGS/1990 \\
\hline \multicolumn{2}{|c|}{ Type of project: acquisition and processing } \\
\hline Total km: & 1915 \\
\hline Funding: & HGS (Halliburton Geophysical Services Inc.) \\
\hline Project: & GGU/1991 \\
\hline \multicolumn{2}{|c|}{ Type of project: acquisition and processing } \\
\hline Total km: & 336 \\
\hline Funding: & MRA \\
\hline Project: & GGU/1992 \\
\hline \multicolumn{2}{|c|}{ Type of project: acquisition and processing } \\
\hline Total km: & 3017 \\
\hline Funding: & MRA \\
\hline
\end{tabular}

\section{Interpretation of new seismic data}

In 1992, provisional interpretation was made of the new seismic data acquired in 1990. In order to provide information about the area offered for licensing to the industry in 1992-93, a summary of the geology and hydrocarbon potential of the offshore southern West Greenland area was made available (Chalmers et al., 1993). This summary included information from all the interpretation work that had been carried out at that time.

A major re-interpretation of the geology of offshore southern West Greenland was completed in April 1994. This interpretation was made primarily on the seismic data acquired and reprocessed from 1989 to 1992 but incorporated both well and gravity data. Results of earlier work were used as guidelines in the interpretation. This project has resulted in the first overview of the whole of offshore southern West Greenland. A summary map showing the structural elements of southern West Greenland is shown in Fig. 2, and sections across the area are shown in Figs 3 and 4.

\section{Geological history}

\section{Plate tectonic setting}

The offshore region of southem West Greenland south of $63^{\circ} \mathrm{N}$ (Fig. 1) is interpreted as a passive continental margin that developed when Greenland and North America separated in the early Tertiary (magnetochron $27 \mathrm{~N}$ ) (Chalmers, 1991; Chalmers \& Laursen, 1995). The Gjoa Rise (Fig. 2) is a volcanic continental margin. Farther south there is a transitional zone between the block-faulted continental crust and oceanic crust in which continental crust appears to have been intruded and overlain by igneous material (Fig. 4). South of $62^{\circ} \mathrm{N}$, half-grabens in an area of highly-subsided crust appear to have been intruded by igneous bodies and peridotite diapirs.

This interpretation contrasts with earlier interpretations such as that of Roest \& Srivastava (1989) which placed the continent-ocean boundary much closer to Greenland than shown in Fig. 2. According to Roest \& Srivastava's (1989) interpretation, sea-floor spreading started during magnetochron 33 (Campanian).

Keen et al. (1994) and Chian \& Louden (1994) present interpretations of the area south of $62^{\circ} \mathrm{N}$ based on single seismic lines. Keen et al. (1994) show two alternative interpretations, one similar to that of Roest \& Srivastava (1989) and the other similar to that shown on Fig. 2. Chian \& Louden (1994) interpret the area landward of magnetic anomaly 27 or 28 as thin continental crust intruded by peridotite diapirs. 


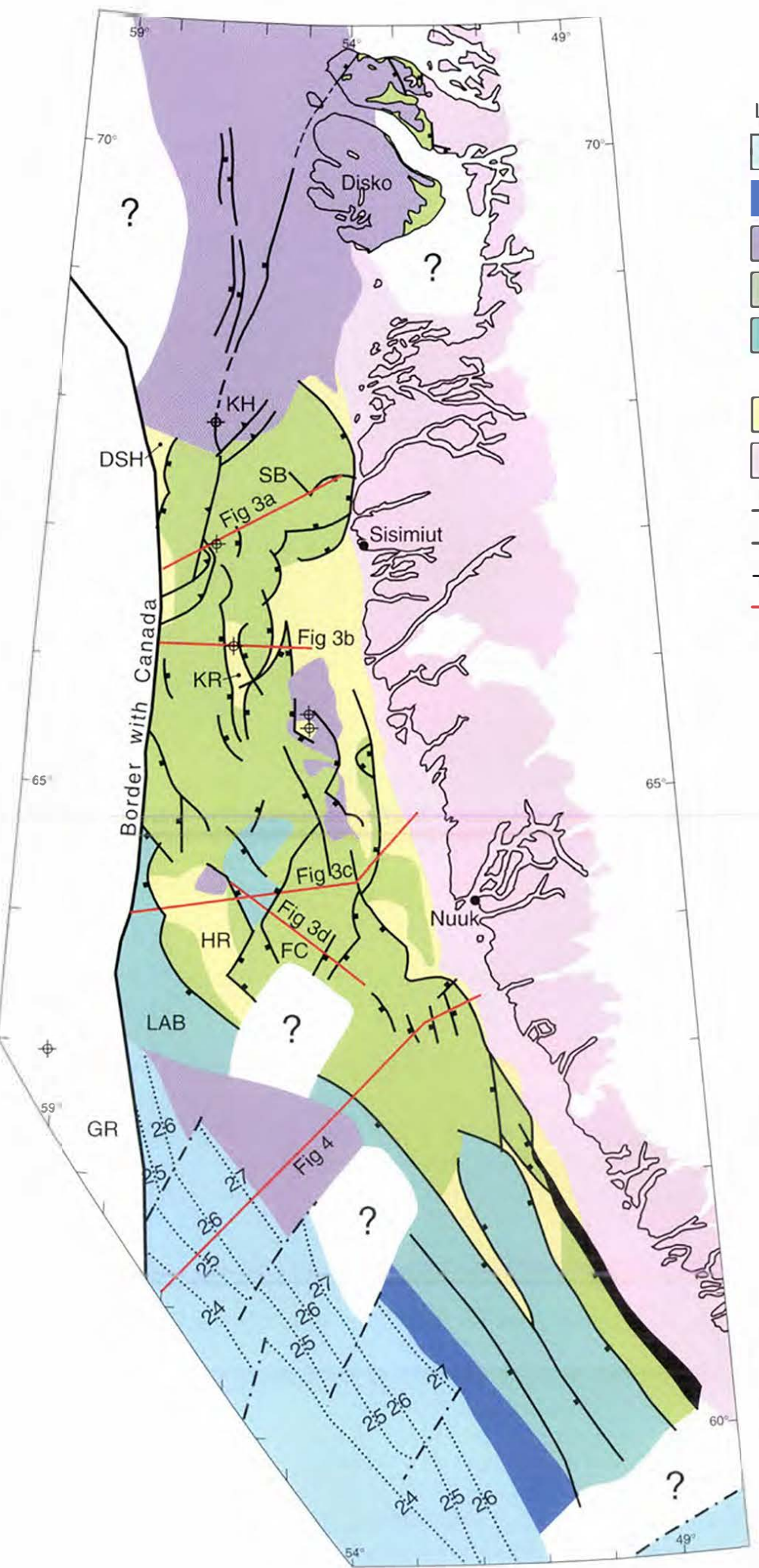

Fig. 2. Map showing the stnuctural elements of the southern West Greenland basin. $\mathrm{KH}$ : Kangeq High. KR: Kangâmiut ridge, SB: Sisimiut basin. DSH: Davis Strat High. HR: Hecla Rise, FC: Fylla structural complex. LAB: Laddy Anne Basin. GR: Gjoal Rise. The positions of cross-sections shown in Figs 3 and 4 are shown. 


\section{Development of pre-Tertiary basins}

The extent of Mesozoic basins is shown in Fig. 2 and cross-sections through them are shown in Figs 3 and 4.

The oldest sequence (the 'deep sequence') identified offshore southern West Greenland is interpreted on seismic sections in the Sisimiut Basin (Fig. 3). These rocks may be Ordovician limestones equivalent to those exposed in eastern Canada (Bell \& Howie, 1990), erosional remnants of which are found in Greenland (Stouge \& Peel, 1979). Other possibilities are Lower Cretaceous volcanics equivalent to the Alexis Formation on the Labrador Shelf (Balk will, 1987) or hitherto completely unknown Mesozoic sediments.

Some time after deposition of the 'deep sequence', halfgrabens developed (Figs 3 and 4). Two sequences, the Kitsissut and Appat sequences (Chalmers et al., 1993), can be interpreted to have been deposited during this period of rifting. None of the wells penetrated these sequences, but we speculate that they may be of Early to mid-Cretaceous

\section{Table 2. Summary of acquisition parameters for surveys GGU/1990, HGS/1990, GGU/1991 and $G G U / 1992$}

$\begin{array}{ll}\begin{array}{ll}\text { Acquisition } \\ \text { Source: }\end{array} & \begin{array}{l}\text { airguns } \\ 1990 \text { and } \\ 1991 \text { and }\end{array} \\ & 25 \mathrm{~m} \\ \text { Shot interval: } & 6 \mathrm{~m} \\ \text { Source depth: } & \\ \text { Streamer length } & \\ \quad \text { (analogue): } & 3000 \mathrm{~m} \\ \text { Streamer depth: } & 8 \mathrm{~m} \\ \text { Number of channels: } & 120 \\ \text { Record length: } & 8 \mathrm{sec} \\ \text { Sample interval: } & 2 \mathrm{msec}\end{array}$

\section{Processing}

Apart from routine processing, all surveys included the following procedures:

Resample to $4 \mathrm{msec}$

Demultiple (f-k for GGU/1990, HGS/1990 and GGU/1991; 'mule' (proprietary process of Spectrum Geophysical) followed by f-k for GGU/1992)

Dip Move-Out (DMO) correction

Velocity analysis every $2 \mathrm{~km}$

Inside trace mute

Cdp-stack (60-fold

Migration (finite difference for GGU/1990, HGS/1990 and GGU/1991; Omega-X for GGU/1992 age because their seismic character is similar to the Lower and Upper Bjarni Formation on the Labrador Shelf (Balkwill, 1987; Balkwill \& McMillan, 1990). The Bjarni Formation is of Early Cretaceous age and sediments of the same age are exposed on the Nuussuaq peninsula (Fig. 2). Syn-rift sediments of mid-Cretaceous age have also been identified on islands north of Nuussuaq by Rosenkrantz \& Pulvertaft (1969).

The Kitsissut and Appat sequences are overlain by the Kangeq sequence (Fig. 3), which is seismically transparent. The uppermost 850 metres of the Kangeq sequence were penetrated by the Ikermiut-1 well (Fig. 3a). Here the sequence consists of marine mudstones of Campanian to Maastrichtian age (Rolle, 1985). The Kangeq sequence has been interpreted by Chalmers et al. (1993) as being deposited during a phase of thermal subsidence that followed the extensional episode recorded by the Kitsissut and Appat sequences. More proximal sediments of the same age as the Kangeq sequence are exposed on Disko, Nuussuaq and Svartenhuk Halvø farther north (Pedersen \& Pulvertaft, 1992; Fig. 1). Proximal sediments may also be present on the southern edge of the Sisimiut Basin where a wedge of sediments prograded off the Nukik platform during mid-Cretaceous times (Henderson et al., 1980; Ottesen, 1991b).

\section{Paleocene tectonism, sedimentation and volcanism}

In parts of off shore southern West Greenland, Paleocene rifting, probably connected to the start of sea-floor spreading in the Labrador Sea, led to the deposition of fans along active faults. The Narssarmiut Formation (Rolle, 1985), which was penetrated by the Kangâmiut-1 well, can be interpreted to be part of one of these fans (Chalmers, 1992; K. J. Bate, unpublished data).

Low energy shelf to deep-water mudstones were deposited widely during the Paleocene (Rolle, 1985). In places, basin floor fans interbedded with the mudstones can be interpreted on the seismic data.

Volcanism appears to have occurred during the Paleocene along all the margins of the Labrador Sea (Balkwill, 1987; Chalmers, 1991; Chalmers et al., 1993; Chalmers \& Laursen, 1995) and, along the Greenland margin, Tertiary dykes and sills were intruded into some of the grabens containing Mesozoic sediments (Figs 2, 3 and 4). The volcanism at the continent-ocean boundary on the Gjoa Rise (Fig. 2) appears to have been sub-aerial, as indicated by seaward-dipping reflectors and a landward-facing marginal escarpment (Chalmers \& Laursen, 1995). This indicates that there were high temperatures in some areas of the upper mantle during the Early Tertiary.

North of approximately latitude $68^{\circ} \mathrm{N}$, Paleocene vol- 

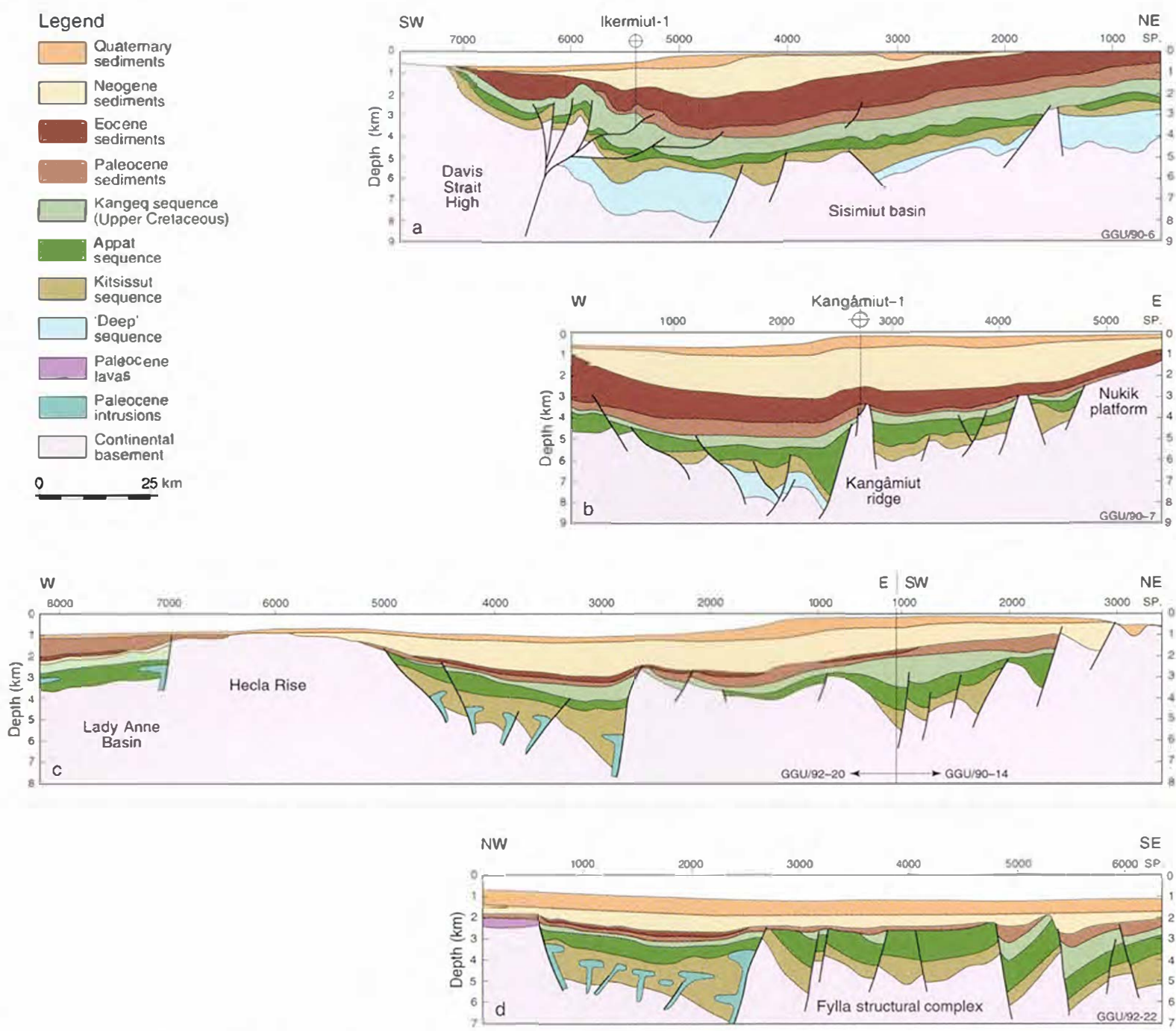

Fig. 3. Selected cross-sections from offshore southern West Greenland based on interpreted and depth-converted seismic lines. Their locations are shown on Fig. 2. Vertical exaggeration 5:1.

canism, probably contemporary with the onset of sea-1loor spreading (Piasecki et al., 1992), led to the extrusion of a thick succession of basaltic lavas (Fig. 2), part of which is exposed onshore (Clarke \& Pedersen, 1976). The Hellefisk- 1 well penetrated the southermmost extent of the lavas (Rolle, 1985). Smaller areas of lava occur farther south (Fig. 2). The lavas that were penetrated by the Nukik-1 well (Rolle, 1985) may have been crupted into actively rifting hall-grabens (Chalmers. 199(): Chalmers et al., 1993).

\section{Eocene}

Following a change in direction of sea-floor spreading at the beginning of the Eocene (magnetochron 24R) (Roest \& Srivastava, 1989; Fig. 2), sedimentation offshore southern
West Greenland took place on a steadily subsiding continental margin. Deposition of mudstones continued during the Early Eocene, but by the Middle and Late Eocene. coarser clastics were being deposited in a high-energy shelf cnvironment (Rolle. 1985).

A period of erosion and relative uplift at the end of the Eocene or in the early Oligocene coincided with the cessation of sea-floor spreading. Along the continental margin south of about $63^{\circ} \mathrm{N}$, the post-drift margin was sediment starved, and this part of the shelf is narrow today (Fig. 4).

No occanic crust is interpreted north of about $63^{\circ} \mathrm{N}$ in the Labrador Sea. We interpret that the movement of North America relative to Greenland was transferred from the Labrador Sea to Baffin Bay by a complex system of strikeslip faults known as the Ungava fault complex through 


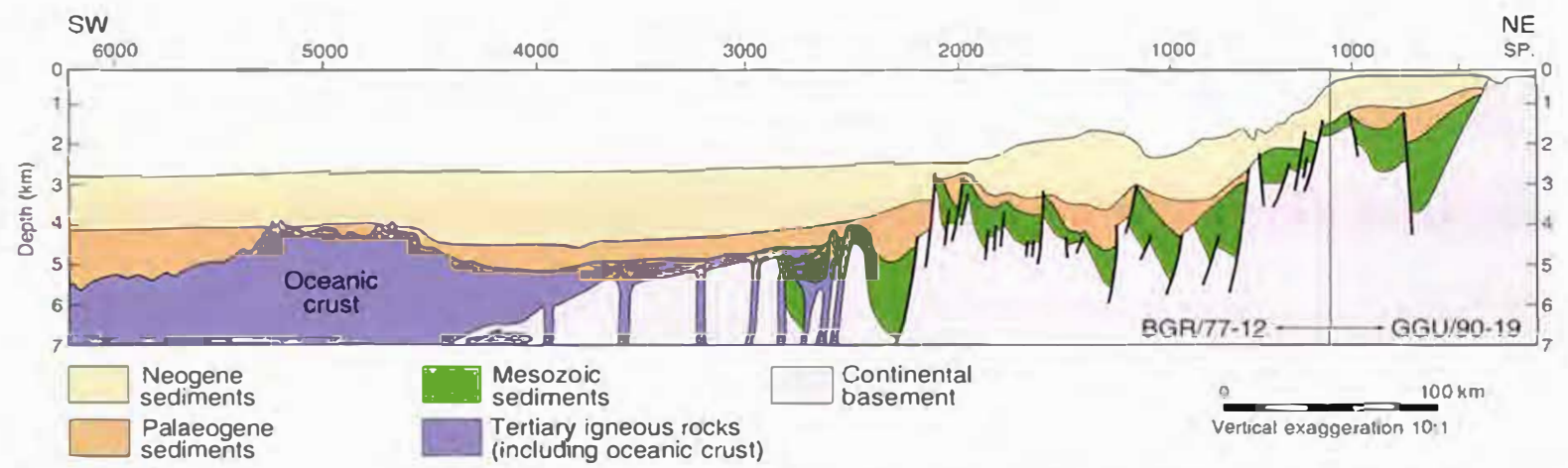

Fig. 4. Cross-section across the transition from continental crust to oceanic crust. Depth converted section based on seismic lines BGR/77-12 and GGU/901)-19(Chalmers. 1991: Chalmers \& Lausen, in press). Vertical exaggeration 10:1. Note difference in vertical exaggeration between this cross-section and those shown in Fig. 3. Location shown in Fig. 2.

continental crust in the region of the Davis Strait (Chalmers et al., 1993). The Davis Strait High is bounded by some of the Ungaval faults, and the fault on its south-eastern side moved in transpression during the Early Tertiary. This gave rise to complex flower structures hetween $66^{\circ} \mathrm{N}$ and $68^{\circ} \mathrm{N}$ (Fig. 2) and the lkermiut-1 well drilled a small fold on the margin of one of them (Fig. 3a). North of about $68^{\circ} \mathrm{N}$. the Ungava fault complex is transtensional. The Itilli fault on western Nuussuag is an extension of this system onshore.

\section{Neogene'}

Evidence for Neogene uplifi can be seen on the seismic sections in the north-eastern part of the Sisimiut Basin (Fig. 2) and onshore West Greenland.

During the Quaternary. prograding wedges of sediment several hundreds of metres thick were deposited as the Greenland ice cap advanced and waned across the continental shelt.

\section{Petroleum prospectivity}

Chalmers \& Pulvertafi ( 1993 ) presented an appraisal of the prospects tested by the tive wells in 1976 and 1977. This work showed that all of the prospects drilled were in some way defective as traps for hydrociarbons. Nukik-1 found only sandstones lying directly on basement with no seal present. Nukik-2 and Hellelisk-1 penetrated Paleocene volcanic rocks under Tertiary sandstones, again with no seal. Ikermiut-l penetrated a thick Lower Tertiary and Upper Creaceous mudstone succession which could form a good seal, but there were no reservoir rocks. Only in Kangâmiut-1 was a possible rescrvoir rock encountered under a possible seal. Gas shows up to C5 were recorded and a Drill-Stem Test (DST) performed. After examination of the original drilling records, it has been realised that probably only drilling-mud thuids were produced during the DST (K. J. Bate. unpublished datia). This suggests that the reservoir may contain hydrocarbons which were never properly iested.

Source rocks. The Upper Cretaceous mudstones encountered by lkermiut-1 contain total organic carbon (TOC) amounts of over 2\% but were gals prone (Rolle, 1985). However, a kilometre of Kangey sequence sediments lie below the T.D. of the well (Fig. 3al). It is therefore possible that the lower part of the Kangec sequence could be of Cenomanian-Turonian age. This is the time of a global anoxic event during which prolitic source rocks were deposited elsewhere in the world (Klemme \& Ulmishek, 1991). Recently. marine mudstones of exactly this age. with TOC contents typically $8 \%$ and more and hydrogen indices of $3(0)(0.50)+$ have been described from the Siverdrup Basin in Arctic Canalda (Núñez-Betelu, 1993).

Mudstones of Early Tertiary age encountered by the Kangâmiut-1 and Ikermiut-1 wells contain cotal organic carbon (TOC) amounts of up 10 over $2 \%$ but are gats prone (Rolle. 1985). Furthermore, oil from a probable Paleocene or latest Cretaceous source rock has been encountered in western Nuussuaq (Christiansen et (1l., 1994).

Reservoirs. The presence of sandstones in the syn-rift environment of the Kitsissut and Appal seyuences can he expected. This was the case in the Bjarni Formation which acts as the reservoir for several gas accumulations on the Labrador Shelf (Balkwill, 1987). Lower Tentary syntectonic fans. which presumably contain sands comparable $(0)$ the Narssarmiut Formation. can be interpreted along the faulted margins of other basement highs and basin floor fans of Early Tertiary age can be interpreted in several areas.

Seuls. Mudstones of the Kangey sequence can seal reservoirs in the Kitsissut and Appat sequences, and mudstones of Paleocene and Eocene age can seal Early Tertiary reservoirs and older reservoirs where the Kangeg sequence has been removed. 
Leads. Three major structural leads and a number of stratigraphic plays have been identified.

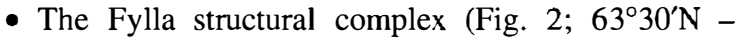
$64^{\circ} 30^{\prime} \mathrm{N} ; 54^{\circ} \mathrm{W}-56^{\circ} \mathrm{W}$ ) was formed by a system of faults that moved in the Early Tertiary. These north-east to southwest trending extensional faults are roughly parallel to the Labrador Sea transform faults. Movement on them led to the formation of large rotated fault-blocks which may be capable of trapping large quantities of hydrocarbons. Flat spots have been interpreted to be present in these structures which, if real, indicate the presence of very large quantities of gas (Bate et al., 1994, this report). Fig. 3d shows a crosssection through these structures.

- In the complex flower structures between latitudes $66^{\circ} \mathrm{N}$ and $68^{\circ} \mathrm{N}$ and west of the Ikermiut- 1 well (Fig. 2), the Kitsissut and Appat sequences are folded and faulted beneath the mudstones of the Kangeq sequence (Fig. 3a). These structures are large but very complex and the present seismic grid is inadequate to resolve individual prospects.

- The Kangâmiut ridge (Figs 2 and $3 b$ ) is a basement ridge about $100 \mathrm{~km}$ long north to south. Its potential remains untested because the Kangâmiut- 1 well, the only well that was drilled on the ridge, did not evaluate it properly.

- Stratigraphic traps may be provided by both syn-tectonic and basin-floor fans of Early Tertiary age and by the large body of sediment that prograded over the southern margin of the Sisimiut basin in mid-Cretaceous times.

\section{References}

Balkwill, H. R. 1987: Labrador basin: structural and stratigraphic style. In Beaumont, C. \& Tankard, A. J. (ed.) Sedimentary basins and basin-forming mechanisms. Mem. Can. Soc. Petrol. Geol. 12, 17-43.

Balkwill, H. R. \& McMillan, N. J. 1990: Geology of the Labrador Shelf, Baffin Bay, and Davis Strait. Part 1: MesozoicCenozoic geology of the Labrador Shelf. In Keen, M. J. \& Williams, G. L. (ed.) Geology of the continental margin of eastern Canada, 295-324. Geology of North America I-1 (also Geology of Canada 2, Geological Survey of Canada). Boulder, Colorado: Geological Society of America.

Bate. K. J.. Whittaker. R. C.. Chalmers. J. A. \& Dahl-Jensen. T. 1994: Fylla complex - possible very large gas reserves off S.W. Greenland. Oil \& Gas Journal 92, 79-82.

Bate, K. J., Whittaker, R. C., Chalmers, J. A. \& Dahl-Jensen, T. 1995: The Fylla structural complex: possible very large gas reserves offshore southern West Greenland. Rapp. Grønlands geol. Unders. 165 (this report).

Bell, J. S. \& Howie, R. D. 1990: Paleozoic Geology. In Keen, M. J. \& Williams, G. L. (ed.) Geology of the continental margin of eastern Canada, 141-165. Geology of North America I-1 (also Geology of Canada 2, Geological Survey of Canada). Boulder, Colorado: Geological Society of America.

Brett, C. P. \& Zarudzki, E. F. K. 1979: Project Westmar. A shallow marine geophysical survey on the West Greenland conti- nental shelf. Rapp. Gronlands geol. Unders. 87, 29 pp.

Chalmers, J. A. 1989: A pilot seismo-stratigraphic study on the West Greenland continental shelf. Rapp. Grønlands geol. Unders. 142, $16 \mathrm{pp}$.

Chalmers, J. A. 1990: Re-evaluation of the geology of the southern West Greenland shelf - Project VEST SOKKEL. Rapp. Grønlands geol. Unders. 148, 29-32.

Chalmers, J. A. 1991: New evidence on the structure of the Labrador Sea/Greenland continental margin. J. geol. Soc. 148 , 899-908.

Chalmers, J. A. 1992: The nature of the basal section in the Kangâmiut-I well, offshore West Greenland. Open File Ser. Grønlands geol. Unders. 92/9, 22 pp.

Chalmers, J. A. \& Dahl-Jensen, T. 1991: Project SYD VEST SEIS $-3285 \mathrm{~km}$ of multichannel seismic data acquired on the southern West Greenland shelf. Rapp. Grønlands geol. Unders. 152, 21-23.

Chalmers, J. A. \& Laursen, K. 1995: Labrador Sea: A new interpretation of the structure of its continental margins and timing of the onset of sea-floor spreading. Marine Petrol. Geol. 12, 205-217.

Chalmers, J. A. \& Pulvertaft, T. C. R. 1993: The southern West Greenland continental shelf - was petroleum exploration abandoned prematurely? In Vorren, T. O. et al. (ed.) Arctic geology and petroleum potential. Spec. Publ. Norweg. Petrol. Soc. 2, 55-66. Amsterdam: Elsevier.

Chalmers, J. A., Pulvertaft, T. C. R., Christiansen, F. G., Larsen, H. C., Laursen, K. H. \& Ottesen, T. G. 1993: The southern West Greenland continental margin: rifting history, basin development, and petroleum potential. In Parker, J. R. (ed.) Petroleum geology of Northwest Europe. Proc. of the 4th Conference, 915-931. London: Geological Society.

Chian, D. \& Louden, K. E. 1994. The continent-ocean crustal transition across the southwest Greenland margin. J. Geophys. Res. 99, 9117-9135.

Christiansen, F. G. \& Pulvertaft, T. C. R. 1992: Petroleum-geological activities in 1991: reassessment of areas of earlier exploration, and improvement of information service to industry. Rapp. Grønlands geol. Unders. 155, 28-30.

Christiansen, F. G., Marcussen, C. \& Pulvertaft, T. C. R. 1993: Petroleum-geological activities in 1992: preparation and support for licensing rounds offshore West Greenland. Rapp. Grønlands geol. Unders. 159, 38-42.

Christiansen, F. G., Dam, G. \& Pedersen, A. K. 1994: Discovery of live oil at Marraat, Nuussuaq: field work, drilling and logging. Rapp. Grønlands geol. Unders. 160, 57-63.

Clarke, D. B. \& Pedersen, A. K. 1976: Tertiary volcanic province of West Greenland. $I n$ Escher, A. \& Watt, W.S. (ed.) Geology of Greenland, 364-385. Copenhagen: Geol. Surv. Greenland.

Denham, L. R. 1974: Offshore geology of northern West Greenland $\left(69^{\circ}\right.$ to $\left.74^{\circ} \mathrm{N}\right)$. Rapp. Grønlands geol. Unders. 63, 24 pp.

Henderson, G., Schiener, E. J., Risum, J. B., Croxton, C. A. \& Andersen, B. B. 1981: The West Greenland Basin. In Kerr, J. W. \& Ferguson, A. J. (ed.) Geology of the North Atlantic Borderlands. Mem. Can. Soc. Petrol. Geol. 7, 399-428.

Hinz, K., Schlüter, H.-U., Grant A. C., Srivastava, S. P., Umpleby, D. \& Woodside, J. 1979: Geophysical transects of the Labrador Sea: Labrador to southwest Greenland. Tectonophysics 59, 151-183.

Keen, C. E., Potter, P. \& Srivastava, S. P. 1994: Deep seismic reflection data across the conjugate margins of the Labrador 
Sea. Can. J. Earth. Sci. 31, 192-205.

Klemme, H. D. \& Ulmishek, G. F. 1991: Effective petroleum source rocks of the World: stratigraphic distribution and controlling depositional factors. Bull. Am. Assoc. Petrol. Geol. 75, 45-69.

Manderscheid, G. 1980: The geology of the offshore sedimentary basin of West Greenland. In Miall, A. D. (ed.) Facts and principles of world oil occurrence. Mem. Can. Soc. petrol. Geol. 6, 951-973.

Núñez-Betelu, L. K. 1993: Rock-eval/TOC pyrolysis data from the Kanguk formation (Upper Cretaceous), Axel Heiberg and Ellesmere Islands, Canadian Arctic. Open File Rep. Geol. Survey Canada 2727, $29 \mathrm{pp}$.

Ottesen, T. G. 1991a: A preliminary seismic stratigraphic study of the Paleocene-Eocene section offshore southern West Greenland between $66^{\circ}$ and $68^{\circ}$ N. Open File Ser. Grønlands geol. Unders. 90/1, $46 \mathrm{pp}$.

Ottesen, T. G. 1991b: A preliminary seismic study of part of the pre-Paleocene section offshore southern West Greenland between $66^{\circ} \mathrm{N}$ and $68^{\circ} \mathrm{N}$. Open File Ser. Grønlands geol. Unders. 91/6, $28 \mathrm{pp}$.

Pedersen, G. K. \& Pulvertaft, T. C. R. 1992: The nonmarine Cretaceous of the West Greenland Basin, onshore West Greenland. Cretaceous Res. 13, 263-272.

Piasecki, S., Larsen, L. M., Pedersen, A. K. \& Pedersen, G. K. 1992: Palynostratigraphy of the Lower Tertiary volcanics and marine clastic sediments in the southern part of the West Greenland Basin: implications for the timing and duration of the volcanism. Rapp. Gronlands geol. Unders. 154, 13-32.
Roest, W. R. \& Srivastava, S. P. 1989: Sea-floor spreading in the Labrador Sea: A new reconstruction. Geology 17, 1000-1003.

Roksandić, M. M. 1979: Geology of the continental shelf off West Greenland between $61^{\circ} 15^{\prime} \mathrm{N}$ and $64^{\circ} 00^{\prime} \mathrm{N}$. Rapp. Gronlands geol. Unders. 92, $15 \mathrm{pp}$.

Rolle, F. 1985: Late Cretaceous - Tertiary sediments offshore central West Greenland: lithostratigraphy, sedimentary evolution, and petroleum potential. Can. J. Earth Sci. 22, 10011019.

Rosenkrantz, A. \& Pulvertaft, T. C. R. 1969: Cretaceous-Tertiary stratigraphy and tectonics in northern West Greenland. Mem. Am. Ass. Petrol. Geol. 12, 883-898.

Stouge, S. \& Peel, J. S. 1979: Ordovician conodonts from the Precambrian Shield of southem West Greenland. Rapp. Grønlands geol. Unders. 91, 105-109.

Toxwenius, B. B. 1986: Compilation of Late Cretaceous - Tertiary biostratigraphic data and correlation of five wells, offshore central West Greenland. Unpublished GGU internal report., $69 \mathrm{pp}$

Tucholke, B. E. \& Fry, V. A. 1985: Basement structure and sediment distribution in Northwest Atlantic Ocean. Mem. Am. Assoc. Petrol. Geol. 69, 2077-2097.

J. A. C., K. J. B. \& R. C. W., Geological Survey of Denmark and Greenland, Copenhagen

T. D.-J., Geological Survey of Denmark and Greenland, Copenhagen. Present address: Danish Lithosphere Centre, Øster Voldgade 10, DK-1350 Copenhagen K, Denmark 